\title{
The Feminization of Physical Culture: The Introduction of Dance Into the American University Curriculum
}

\author{
Janice Ross
}

My dissertation takes as its point of departure the introduction of dance classes into the American university curriculum. The classes I am studying were exclusively for women and were initiated in 1917 at the University of Wisconsin at Madison. What I want to understand is how this art form, only twenty years earlier reviled as an unhealthy and degenerate practice, entered the academy as a respectable subject for women, although not for men. I am also studying the emergence of dance in the university as part of the larger social transformation of women's place from the private to the public sphere. I want to examine these changes against the background of the American University's role in helping to create and perpetuate ideals of womanhood as well as in framing the arts as socially functional disciplines.

My research methodologies will be drawn from cultural history and feminist inquiries into turn of the century female health and exercise practices. In addiction, I am using studies in material culture as models to help me analyze the Victorian woman through artifacts such as studios/gyms created for these first dance classes and the special costumes the dance students wore. My research will look for the historical interconnectedness between the general public regard for dance, new agendas for higher education, and changes in women's social status in late 19 th and early 20 th century in America.

In particular, I want to examine the larger social context that frames this first acceptance of dance as an art form into the American university curriculum. I also want to trace how this institutionalizing of a performing art served to both legitimize and constrain dance practices involving women's bodies in education. This first acknowledgment of women's physical bodies in American higher education carried with it a number of implicit beliefs about making the dancing body more about personal expression than physical display. It also initiated a new consideration of the female body in education as an entity where intellectual and spiritual growth were supported rather than undermined by the proper physical training.

I will being by exploring the recondite historical and contemporary links between the cultural and political climate of the late 19th and early 20th century America, the university, and dance. In particular, I want to examine the larger social context framing the acceptance of the art discipline of dance into the American university curriculum in 1917, and the subsequent establishment of the first dance maior in 1926.

My research will delineate the complex relationships between social reform, education, and the status of dance in American society in the last third of the Nineteenth Century. This knowledge is foundational for understanding the social and moral tensions surrounding status of dance as a theater form at

Marilyn Zurmuehlen's Working Papers in Art Education 1996-1997 
the turn of the century. This will be background for looking at the forces that helped to transform it into an academic discipline. Woven inextricably into this story are shifts in national educational reform agendas and changing women's roles. This chapter will explore the status of the body in education and society during this period, the theater as a site of danger for virtuous women, and the social status of women in the public sphere of the university.

My interest is in not only illuminating the beginnings of dance in higher education, but also to introduce this historical scholarship as a basis for better understanding the pressing problems of dance in the university today.

The situation for all the arts in American education, and particularly dance, is riddled with paradoxes. A 1990 Louis Harris Nationwide Survey of Public Opinion reported that $91 \%$ of Americans Support the arts in education, yet the influential 1988 study, Toward Civilization: A report on Arts Education, prepared by the National Endowment for the Arts at the request of Congress, concluded "In general arts education is characterized by imbalance, inconsistency and inaccessibility." (Levine 1994) Indeed. among all the constraints that impact the curriculum in higher education, no disciplines feel it so as the arts. Yet, as many Americans seem to realize, the consequences of an artless education is an artless culture.

This will be a cultural history of the beginnings of dance, as one of the more contested art disciplines in American higher education. It will be set against the larger historical context of the university policies and politics. In 1994, Dance/USA, the Washington-based national dance service organization, noted after a year-long examination of dance in American education. "The place of dance education within the university is far from secure...Advances over the last two decades are being undermined as budgetary constraints lead universities to streamline or eradicate programs." (Levine 1994) These funding uncertainties may well be tied to larger issues of knowledge legitimation and the historical roots of dance in academia.

My research will include an overview of the present position of dance in higher education in America. While the field of dance in higher education has boomed numerically in the 78 years since dance entered the curriculum (the 1994-5 Dance Magazine College Guide lists 565 colleges and universities that offer degrees in dance), (McCormack 1994) most recently it has been marked by instability and fragmented objectives and identities. by way of introduction to the historical beginnings of dance I will look at five different college dance programs-those of the University of Wisconsin at Madison, Bennington College, Mills College, the University of California at Los Angeles and Stanford University. The situation at each is distinct yet similar, for each program now faces major challenges of redefinition, reconstitution or reconceptualization if it is to survive as a vigorous program into the next millennium.

What of the early history of dance education might be relevant for thinking about these current constraints on the roles of the performing arts in higher education? At the moment the situation for dance in higher education is 
very uncertain: The University of Wisconsin at Madison, the oldest program, ceased granting degrees for nearly 10 years and is only now preparing to seek university approval to resume granting degrees. (Interestingly the woman heading it is a dance historian on loan from the Theater Department which in itself suggests a major ideological shift and one perhaps challenging the long standing division between dance as an activity or an art form UW initiated.) UCLA, long one of the most reputable dance programs in the nation, ceased using the word dance for its movement classes in the fall of 1995 when it launched a new World Arts and Cultures Department with traditional modern dance only one of many players. Bennington College's dance program, founded in the 1930's, soon after UW's, currently only has 2 graduate students a year. Mills College's dance program is operating on a model that hasn't changed significantly since the 1950's.

My research will offer a fresh historical context for viewing these portraits of dance in higher education today. Among the questions I hope to answer is that of the frequent mis-perception of the performing arts, and particularly dance, as merely narrow recreational or entertainment activities. In what way might this outlook be rooted in the initial conceptions of dance when it first entered the university seventy-eight years ago?

How were the tensions between the various facets of dance as a physical art form and an intellectual discipline negotiated in the University? What of this 1917 accommodation might have made for lingering tensions in the academy? How was dance framed as an art form and an intellectual enterprise in the first two decades of the 20th century, and what was the balance that was articulated between it as a physical experience and an art discipline? Why are so many dance programs today in trouble?

As part of my research, 1 am studying photographs, lesson plans, reminiscences of students and faculty, as well as conducting numerous interviews with students from this early period. I am also looking at archival documents from the personal collections of the chair of Women's Physical Education, Blanche Trilling and those of Margaret H'Doubler, the instructor who taught the first dance class.

My description will strive to offer as vivid a sense as possible of the classroom, curriculum, and academic ambiance of that maiden year for dance in an American university. I will examine the maturing of dance at the University of Wisconsin into a full-fledged undergraduate major in 1924 and a graduate major in 1928. In particular, I will explore the relationship of educational progressivism and vocationalism to the structuring of this first dance major which was designed to produce dance teachers for American schools.

I will explore how dance solidified its base in the university during this decade of the 1920's and early 1930's against a backdrop of the social and cultural climate of America during this period. I will also steadily contrast this with the situation of dance as it developed as a performing art outside the university.

Marilyn Zurmuehlen's Working Papers In Art Education 1996-1997 
This period saw the solidification of the new American art form of modern dance. What needs did dance serve in the university and in society?

I am seeking to discover patterns, a rationale, and significant links between the complex and multifaceted world of early Twentieth Century culture and the equally complicated culture of American higher education. For me the search begins with dance, which has been my primary focus as a critic, historian, and educator for nearly two decades. In addition my background as a journalist, a staff dance critic for a metropolitan daily newspaper, has conditioned my interest in looking at what usually goes unexamined.

Much has been written about the contested status of arts funding in America in recent years, about the emergence of culture as an ideological battleground, and the university as a forum for revisionist readings of Western culture, particularly literature. However, in regard to the visual and performing arts, no one has looked both broadly and closely at the origin and status of their present state within the university.. this research is particularly timely given spreading confusion about the role of the arts both inside and outside the academy today.

Therefore, by combining the methodologies of investigative cultural reporter, an educational researcher, a social historian, and a dance critic, I hope to shed new light on a pivotal but little explored realm of higher education, history. and dance education. the larger realm I speak of is that of the emergence of a cultural hierarchy for the arts in the American university. With the advent of recent scholarship about culture and politics, women in society, the body as a medium on which social values are inscribed, and institutional agendas within higher education, the time is right for a rigorous and comprehensive, investigation into this material.

As the music historian Leonard Meyer has noted in his aesthetic exploration of music however, questions about one art form continually lead to questions about other arts and, more broadly, about the ideas and belieis that characterize our culture. (Meyer 1967) Yet I believe that methodologically the corollary is also true, that the search for relationships between the arts, society and education, can initially be traced most clearly by narrowing one's gaze to a single defining art form, in this instance dance

I want to extend the filaments of my search to include educational institutions as well as curriculum. Particularly in the United States, higher education has served as our most influential forum for intellectual thinking and learning. Society's imprimatur of approval on a discipline is often reflected by the inclusion of that subject within the university curriculum. Yet correspondingly, as Emil Durkheim has illustrated, "We progress in studying change in systems of higher education by pursuing the question as to how their structures and beliefs, their many parts individually and collectively, constrain and induce changes." (Clark 1984) 
This leads one to wonder if it might also be true that where and how a discipline like dance, is placed within the university also reflects and reinforces the social regard for that art form outside the university?

As Lawrence Veysey notes in his history of the American university, "The university must be understood as a magnet for the emotions, not alone as a project of conscious definition." (Veysey 1965) the arts too reflect social issues and concerns more readily than they manufacture them. A close examination of the arts in the university then offers rich possibilities for reading into cultural dispositions through the arts, the university's regard for them, and back into society. In this study my aim is to stand on the metaphorical magnet Veysey speaks of and survey what clings to it, and why, and where it comes from.

My conclusions will, I hope, offer insights on the fundamental question of What does all this information and exploration mean for American schools? What insights does it have to offer that might improve the lot of dance programs in higher education today? What kind of tailoring has dance as a discipline had to undergo to earn a place in academia? Are there lessons here for the cultural shaping universities exert on the arts?

It is my hope that, in providing answers to these question, this study will help make a case for the importance of dance in the education of people. This early tale of dance in academia may reveal useful things about the link between cultural agendas and academic legitimacy. What is the connection between larger cultural ambitions for the nation and the social and academic esteem art knowledge is accorded?

My quest in this study is normative. My aim is to historically investigate how dance came to be a worthy academic subject for the American woman and in doing so to help improve current reassessments of the place of the arts-particularly dance--in higher education. A critical reading of the history of both dance and its first decade of curricular and institutional history in higher education, is the ideal way to undertake such a quest. It is through an awareness of history that we come to recognize the flow of events and discover how significantly the past conditions and shapes the present as well as our perception of it. Therefore, rather that retreating from the problems of the moment for the arts in the university, this examination is a studied look back as a prelude to surging forward with a more firmly grounded understanding of how things came to be and the forces both encouraging and mitigating against change.

In the process of undertaking this historical examination, I also hope to provide higher education with a cautionary tale about the long term costs of making short term pragmatic decisions about curriculum. fundamentally however, as an educator and art advocate, I am interested in helping higher education professionals situate the arts more centrally in the University curriculum and also to reveal the university curriculum as being more central to the arts. By this last statement I mean to prompt a recognition that over time what we have valued in higher education institutions are qualities of perception, understanding and ways of knowing the world that are in fact integral to all intellectual enterprises 
and particularly the arts. I have an interest in using the arts to make a positive difference in the lives of those who attend our schools. I want to use educational history and inquiry as "a major resource for helping the rest of us better understand how to deal with the problems we face," (Eisner 1989). Doing this necessitates understanding how the arts have been developed and used in education up until now. 